\title{
Manajemen Pelayanan Prima dalam Meningkatkan Kualitas Manajemen KBIH
}

\author{
Rik Rik Pahlijan*, Ahmad Sarbini, \& Dewi Sa'diah \\ Jurusan Manajemen Dakwah, Fakultas Dakwah dan Komunikasi, \\ UIN Sunan Gunung Djati, Bandung \\ *Email: Rikrikpablijan@gmail.com
}

\begin{abstract}
ABSTRAK
Penelitian ini menjelaskan regulasi layanan yang diterapkan di KBIH Bintaldam III/Siliwangi, fasilitas-fasilitas layanan dan budaya pemberian layanan dalam meningkatkan kualitas manajemen KBIH. Metode yang digunakan dalam penelitian ini adalah studi deskriptif.. Analisis data dengan analisis kualitatif. Hasil penelitian menunjukkan bahwa regulasi layanan di KBIH Bintaldam III/Siliwangi berguna untuk memberikan jaminan kepada jamaah akan kualitas pelayanan, meningkatkan akuntabilitas dan memperjelas target pekerjaan. Fasilitas-fasilitas layanan di KBIH Bintaldam III/Siliwangi senantiasa diperbaiki dan ditingkatkan demi memberikan pelayanan prima terhadap jamaah. Budaya pelayanan prima di KBIH Bintaldam III/Siliwangi terdiri dari beberapa pilar, yaitu disiplin, ramah, dan melakukan pemberdayaan alumni. Tentunya regulasi layanan, fasilitas-fasilitas layanan dan budaya pelayanan prima sangat memiliki peranan penting dalam meningkatkan kualitas manajemen $\mathrm{KBIH}$ serta dalam melayani dan membantu para jamaah mulai dari proses pendaftaran haji, manasik haji, pemberangkatan jamaah haji ke tanah suci hingga kembali ke tanah air.
\end{abstract}

Kata Kunci: Manajemen; Pelayanan Prima; Kualitas; KBIH

\section{ABSTRACT}

This study explains the regulation of services implemented in KBIH Bintaldam III / Siliwangi, service facilities and service delivery culture in improving the quality of management of $\mathrm{KBIH}$. The method used in this research is descriptive study with data collection techniques conducted are observation, interview, and documentation. Data analysis with qualitative analysis. The results show that service regulation in $\mathrm{KBIH}$ is useful to provide assurance to the congregation of the quality of service, increase accountability and clarify the target work. Service facilities at KBIH Bintaldam III / Siliwangi are constantly improved and upgraded to provide excellent service to pilgrims. The culture of excellent service at KBIH Bintaldam III / Siliwangi consists of several pillars, discipline, friendly, and empowering alumni. Service regulation, service facilities and excellent service culture have an important role in improving the quality of management of $\mathrm{KBIH}$ and in serving and assisting pilgrims starting from the process of Hajj registration, Haij pilgrimage, departure of pilgrims to the Holy Land until returning to the country.

Keywords: Management; Excellent service; Quality; KBIH 


\section{PENDAHULUAN}

Ajaran Islam adalah konsepsi yang sempurna dan komprehensif, karena ia meliputi segala aspek kehidupan manusia, baik yang bersifat duniawi maupun ukhrawi. Islam secara teologis merupakan sistem nilai dan ajaran yang bersifat ilabiah dan transenden. Sedangkan dari aspek sosiologis Islam merupakan fenomena peradaban, kultural, dan realitas sosial dalam kehidupan manusia (Munir, 2006:1).

Islam adalah agama dakwah, yaitu agama yang menugaskan umatnya untuk menyebarkan dan menyiarkan Islam kepada seluruh umat manusia. Sebagai rahmat bagi seluruh alam. Islam dapat menjamin terwujudnya kebahagiaan dan kesejahteraan umatnya umat manusia, bilamana ajaran islam yang mencakup segenap aspek kehidupan itu dijadikan sebagai pedoman hidup dan dilaksanakan dengan sungguh-sungguh. Usaha untuk menyebarkan islam, dapat direalisasikan ajarannya di tengah-tengah kehidupan umat manusia yang merupakan usaha dakwah, dalam keadaan bagaimanapun dan di manapun harus dilaksanakan oleh umat Islam (Shaleh, 1977:11).

Pada hakekatnya tujuan dakwah adalah untuk mendorong manusia atau umat islam ke arah kehidupan yang lebih baik, sejahtera dunia dan akhirat. Agar tujuan dakwah dapat tercapai, maka tentulah diperlukan komponen-komponen atau unsur-unsur dakwah secara baik dan tepat. Adapun salah satu komponen atau unsur tersebut ialah media dakwah. Kelompok Bimbingan Ibadah Haji (KBIH) merupakan salah satu media dakwah terutama dalam hal yang terkait dengan ibadah haji.

Haji pada hakekatnya merupakan sarana dan media bagi umat Islam untuk melaksanakan ibadah ke Baitullah dan tanah suci. Karena setiap tahun sebagian kaum muslimin dari seluruh dunia datang untuk menunaikan ibadah haji. Asal makna kata "haji”" adalah menyengaja sesuatu. Haji yang dimaksud menurut syara' adalah sengaja mengunjungi ka'bah untuk melakukan beberapa amal ibadah dengan syarat-syarat tertentu. Haji diwajibkan atas orang-orang yang kuasa, satu kali seumur hidupnya (Rasyid, 2002:35).

Bagi setiap muslim, termasuk muslim di Indonesia, ibadah haji memiliki makna sangat penting. Dalam konteks Indonesia, ibadah haji tidak hanya dilihat sebagai salah satu rukun Islam yang wajib dilaksanakan kaum Muslimin bagi mereka yang mampu tetapi juga memiliki makna sosiologis dan historis sangat berarti. Secara sosiologis dan historis, dapat dikatakan bahwa perkembangan Islam Indonesia tidak bisa terlepas dari ibadah haji (Basyuni, 2008).

Besarnya minat masyarakat untuk menunaikan ibadah haji, tentunya menuntut berbagai perubahan dan perbaikan dari berbagai pihak penyelenggara, sesuai dengan kondisi dan arah zaman yang berubah. Mungkin pada era 90-an tuntutan kualitas tidak menjadi keharusan bagi masyarakat haji, yang penting bagi mereka adalah berangkat dan kembali dengan selamat serta menjadi haji yang mabrur. Namun tidak demikian untuk jamaah saat ini. Dinamika penyelenggaraan haji selalu menjadi topik pembicaraan yang hangat dikalangan masyarakat. Hal ini karena tuntutan publik di era reformasi dan keterbukaan, dan juga kenyataan 
bahwa haji bukan hanya rutinitas tahunan yang menjadi kewajiban umat Islam dalam menyempurnakan rukun Islam yang kelima, tetapi lebih dari itu, perlu ditingkatkan sistem dan mekanisme penyelenggaraan haji itu sendiri.

Kelompok Bimbingan Ibadah Haji (KBIH) merupakan lembaga sosial Islam yang bergerak dalam bidang Bimbingan Manasik Haji terhadap calon jamaah/jamaah haji baik selama pembekalan di tanah air maupun pada saat ibadah haji di Arab Saudi. Kelompok Bimbingan Ibadah Haji (KBIH) sebagai lembaga sosial keagamaan (non pemerintah) merupakan sebuah lembaga yang telah memiliki legalitas pembimbingan melalui Undang-undang dan lebih diperjelas melalui sebuah wadah khusus dalam struktur baru Departemen Agama dengan Subdit Bina KBIH pada Direktorat Pembinaan Haji (BPPH, 2006:1).

KBIH Bintaldam III/Siliwangi hadir untuk membantu, membina, mengayomi calon jamaah haji agar dapat memberikan solusi yang tepat terhadap permasalahan yang dihadapi jamaah baik di tanah air maupun di tanah suci. KBIH Bintaldam III/Siliwangi didirikan dengan tujuan untuk mendampingi jamaah dalam menjalankan ibadah haji sesuai dengan kaidah fiqh menuju haji mabrur. Dalam meningkatkan kualitas pengelolaan di KBIH tentunya diperlukan strategi pelayanan yang sangat baik mulai dari perencanaan, pengorganisasian, penggerakan sampai evaluasi itu semua dilakukan agar proses pelaksanaan ibadah haji mulai dari tanah air hingga kembali lagi ke tanah air dapat berjalan dengan apa yang diinginkan sehingga mampu mencetak haji yang berkualitas. KBIH ini memiliki keunikan tersendiri karena dikelola oleh aparat TNI. Walau begitu, jama'ah haji di KBIH ini selalu banyak dari tahun ke tahun. Biaya manasik haji di $\mathrm{KBIH}$ tersebut pun dinilai paling murah diantara KBIH lainnya. Sayangnya, dalam lembaga $\mathrm{KBIH}$ tersebut terdapat beberapa problematika. Diantaranya yaitu kurangnya sumber daya manusia untuk mengelola lembaga tersebut, kemudian tidak adanya strategi marketing yang cukup signifikan untuk menginformasikan eksistensi KBIH tersebut kepada masyarakat luas. Namun secara keseluruhan, pelayanan dan manajerial di KBIH Bintaldam III/Siliwangi dinilai berjalan dengan lancar dan baik.

Maka dari itu, penelitian ini mencoba untuk memaparkan berbagai macam persoalan, budaya dan manajemen pelayanan prima terhadap peningkatan kualitas pengelolaan KBIH tersebut. Karena dengan pelayanan dan kualitas yang baik, maka hasil atau kepuasan yang dirasakan oleh para calon jamaah haji akan baik, begitu pula sebaliknya. Petugas/pengurus lembaga tersebut pun akan merasakan dampak baiknya.

Dari latar belakang masalah tersebut dapat dirumuskan beberapa masalah dengan rumusan masalah: bagaimana regulasi layanan, fasilitas-fasilitas layanan dan budaya pemberian layanan di KBIH Bintaldam III/Siliwangi?

Metode yang digunakan dalam penelitian ini adalah studi deskriptif dengan teknik pengumpulan data yang dilakukan adalah observasi, wawancara, dan dokumentasi. Analisis data dengan analisis kualitatif. 


\section{LANDASAN TEORITIS}

Teori yang dijadikan landasan dalam penelitian ini adalah teori manajemen dan pelayanan prima. Manajemen adalah ilmu dan seni mengatur proses pemanfaatan sumber daya manusia dan sumber-sumber lainnya secara efektif dan efisien untuk mencapai suatu tujuan tertentu (Hasibuan, 2011:2).

Manejemen memiliki peran yang cukup penting dalam menjalankan segala hal. Tak kalah penting dengan perannya tersebut, manajemen pun memiliki arti. Secara etimologis, kata manajemen berasal dari Bahasa Inggris, yakni management, yang dikembangkan dari kata to manager, yang artinya mengatur atau mengelola. Kata manager sendiri berasal dari Bahasa Italia, maneggio, yang diadopsi dari Bahasa Latin managiare, yang berasal dari kata manus, yang artinya tangan (Samsudin, 2006:15).

Selain memiliki tujuan dan sasaran yang jelas, manajemen pun memiliki fungsi. Fungsi manajemen adalah rangkaian berbagai kegiatan yang telah ditetapkan dan memiliki hubungan saling ketergantungan antara yang satu dengan lainnya yang dilaksanakan oleh orang-orang dalam organisasi atau bagian-bagian yang diberi tugas untuk melaksanakan kegiatan (Munir, 2009:81).

Dari semua ruang lingkup manajemen mencakup tujuan, sasaran, dan fungsinya, dipadukan menjadi suatu susunan yang sistematis. Manajemen adalah proses perencanaan (Planning), Pengorganisasian (Organizing), pengarahan (Actuating) dan pengawasan (Controlling), usaha-usaha para anggota organisasi dan penggunaan sumber daya-sumber daya organisasi lainnya agar mencapai tujuan organisasi yang telah ditetapkan (Handoko, 1986:8).

Mengutip tentang teori ilmu manajemen yang amat berpengaruh bagi kelangsungan organisasi, yaitu "Ilmu (science) adalah sekumpulan pengetahuan yang telah disistematisasikan, dikumpulkan, dan diterima menurut pengertian kebenaran umum mengenai keadaan suatu subjek dan objek tertentu. Science Management (manajemen ilmiah) adalah suatu kumpulan pengetahuan yang disistematisasi, dikumpulkan, dan diterima menurut pengertian kebenarankebenaran universal mengenai manajemen. Scientific management adalah manajemen yang menggunakan ilmu (science) dan science method. Scientific method adalah suatu pendekatan yang tepat terhadap suatu objek ilmu dan tujuan utamanya ialah untuk menambah pengetahuan yang sudah ada" (Hasibuan, 2011:14).

Menjalankan semua aturan dan semua kegiatan dalam suatu organisasi yang telah diatur dalam suatu SOP tentunya untuk mencapai suatu tujuan. Tujuan/sasaran manajemen adalah sesuatu hasil (khusus) yang ingin dicapai melalui proses manajemen (Hasibuan, 2011:17).

Dalam mencapai tujuan manajemen, tentunya diperlukan unsur-unsur yang dapat berpengaruh bagi kelancaran dan keberhasilan pencapaian tujuan tersebut. Unsur-unsur manajemen terdiri dari 6 unsur, yaitu men, money, methods, materials, machines, market (Hasibuan, 2011:20).

Berkaitan dengan pelayanan, ada dua istilah yang perlu diketahui, yaitu 
melayani dan pelayanan. Pengertian melayani adalah "membantu menyiapkan (mengurus) apa yang diperlukan seseorang". Sedangkan pengertian pelayanan adalah "usaha melayani kebutuhan orang lain" (Kamus Besar Bahasa Indonesia, 1995).

Program pelayanan kepada pelanggan dengan bertitik tolak dari konsep kepedulian kepada konsumen terus dikembangkan sedemikian rupa, sehingga sekarang ini program layanan/pelayanan telah menjadi salah satu alat utama dalam melaksanakan strategi pemasaran untuk memenangkan persaingan. Kepedulian kepada pelanggan dalam manajemen modern telah dikembangkan menjadi suatu pola layanan terbaik yang disebut sebagai layanan prima atau pelayanan Prima. Pelayanan pada dasarnya adalah kegiatan yang ditawarkan oleh organisasi atau perorangan kepada konsumen (customer/yang dilayani), yang bersifat tidak berwujud dan tidak dapat dimiliki (Norman, 1991:14).

Banyaknya pengguna jasa atau mitra suatu perusahaan/lembaga dapat ditentukan oleh faktor pelayanannya. Kepuasan pengguna jasa tentunya mencerminkan bahwa pelayanan dalam lembaga tersebut cukup prima bahkan sangat baik. Pelayanan prima adalah pelayanan dengan standar kualitas yang tinggi dan selalu mengikuti perkembangan kebutuhan pelanggan setiap saat, secara konsisten dan akurat (handal). Berorientasi kepada kepuasan pelanggan, selalu mengikuti perkembangan standar internasional /ISO, dan menerapkan manajemen mutu total/ konsistensi dan kesadaran mutu yang tinggi (high quality consciousness) seperti customer orientation (focus pelanggan), QC-Circles (siklus kendali mutu), automation (otomatisasi), discipline in the workplace (disiplin), equality improvement (perbaikan mutu), zero defect (kerusakan nol), dan sebagainya (Rahmayanty, 2010:18).

\section{HASIL DAN PEMBAHASAN}

Sejak tahun 1990 sampai dengan 1998 yang membantu melayani masyarakat dalam beribadah haji adalah Departemen Agama, adapun untuk anggota TNI (ABRI) waktu itu beserta keluarganya (KBA) yang akan beribadah haji dilayani oleh suatu wadah yang disebut Badan Koordinasi Urusan Haji (BAKUH) ABRI, walaupun secara tekhnis dan administratif Departemen Agama yang menyelenggarakan. Untuk Kodam termasuk Kodam III/Slw, berkaitan dengan pelayanan Ibadah haji keberadaannya waktu itu merupakan kepanjangan dari BAKUH ABRI yang membantu melayani perhajian yang berada di daerah. Bintaldam III/Slw yang secara fungsional didalamnya ada tugas Bimbingan Rohani (Bimroh) yang antara lain berkaitan dengan ibadah haji, dan didukung oleh kepercayaan masyarakat walaupun masih kurang dari 20 orang waktu itu, berupaya membantu melayani dan mengkoordinasikan langsung dengan instansi terkait termasuk BAKUH ABRI. Namun karena jumlah jamaah haji dari Kodam III/Slw kurang dari 20 orang, maka yang membimbing langsung dari BAKUH ABRI Pusat Jakarta. Adapun menurut ketentuan waktu itu, tiap 49 orang dibimbing oleh 
1 orang Pembimbing/ Ketua Rombongan (Karom), jadi tiap rombongan berjumlah 50 orang.

Sejak tahun 1999, sesuai dengan undang-undang nomor 17 tahun 1999, tentang penyelenggaraan Ibadah Haji dan Keputusan Menteri Agama Ri Nomor 224 memberikan surat ijin operasional Kelompok Bimbingan Ibadah Haji (KBIH) kepada Kodam III/ Slw, Pada waktu itu Ketua KBIH nya Letkol Drs. H. Ma'mun Syahroni sebagai Kabintaldam III/ Slw dengan pertimbangan bahwa jamaah haji waktu itu berjumlah hampir 2 kloter (670) yang dibimbing oleh 12 orang Pembimbing.

Walaupun Kodam III/ Slw bukan merupakan yayasan/majelis ta'lim, sesuai UU no. 17 tahun 1999 tersebut, tetapi dengan jumlah jumaah sudah lebih dari 50 orang dari tahun ke tahun kepercayaan masyarakat untuk bergabung dengan KBIH Bintal Umat semakin bertambah dan sekaligus melaksanakan fungsi territorial, maka Departemen Agama memberikan kekhususan. Seiring dengan keluarnya UU no. 17 tahun 1999 dan Keputusan Menag RI no. 224 tahun 1999 tersebut maka Badan Koordinasi Urusan Haji ABRI (BAKUH ABRI) dinyatakan tidak ada lagi dan sebagai penggantinya adalah Kelompok Bimbingan Ibadah Haji $(\mathrm{KBIH})$ sampai sekarang. Pada dasarnya, lembaga resmi / institusi pemerintahan khususnya TNI tidak boleh mendirikan lembaga $\mathrm{KBIH}$, namun karena di dalam fungsi pembinaan mental di Kodam III/Siliwangi ini ada fungsi perawatan khususnya pembinaan haji juga banyak permintaan untuk mendirikan KBIH. Kemudian permintaan itu disetujui oleh Panglima TNI dan Departemen Agama. Maka terbentuklah KBIH Bintaldam III/Siliwangi.

Lokasi penelitian ini dekat dengan mall Bandung Indah Plaza. Bagi yang sering olahraga di GOR Saparua, mungkin sudah tahu lokasi Kodam III/Siliwangi. Jika ditempuh melalui kendaraan pribadi dari Cileunyi, rutenya melalui Cicaheum, kemudian melewati jalan Riau dan jalan Banda. Jika telah melewati jalan tersebut, maka akan segera tiba di jalan Aceh yakni Kodam III/Siliwangi. Jika sedang berada di GOR Saparua, cukup dengan berjalan kaki karena lokasi penelitian sangat dekat.

Hasil penelitian ini menemukan regulasi layanan, fasilitas-fasilitas layanan dan budaya pemberian pelayanan di KBIH Bintaldam III/Siliwangi dalam meningkatkan kualitas manajemen KBIH.

\section{Regulasi layanan di KBIH Bintaldam III/Siliwangi}

Service Regulation atau peraturan layanan ini penting adanya guna menyusun, mengembangkan jasa pelayanan pada pelanggan/jamaah mencakup sistem, aturan, keputusan, prosedur dan tatacara pelayanan dan keluhan agar memudahkan dalam standar pelaksanaan pelayanan serta berguna menyampaikan produk dan atau jasa perusahaan/lembaga terkait. Regulasi layanan tersebut termuat dalam standar pelayanan atau disebut juga dengan SOP (Standard Operating Procedures) yang dibuat untuk menghindari terjadinya variasi dalam proses pelaksanaan kegiatan oleh pegawai yang akan mengganggu kinerja organisasi secara keseluruhan. Di KBIH ini pun memiliki SOP sehingga setiap langkah 
kegiatannya pun jelas. Adapun regulasi mengenai ruang lingkup tugas $\mathrm{KBIH}$, diantaranya:

Pertama, persiapan meliputi rapat, pendaftaran jamaah calon haji, menentukan calon ketua rombongan, menentukan program bimbingan haji, penyampaian informasi seputar haji, koordinasi dengan instansi terkait kegiatan haji, pemeriksaan kesehatan dan pembuatan paspor, silaturahmi awal jamaah calon haji. Kedua, pengadministrasian meliputi daftar ulang calon jamaah haji, melengkapi administrasi calon jamaah, menentukan/menyusun daftar regu/rombongan, menyediakan perlengkapan calon jamaah. Ketiga, penataran/pembekalan manasik meliputi menyiapkan petugas penatar, membuat jadwal penataran, menyiapkan materi penataran, menyiapkan alat/perlengkapan penataran, pembukaan penataran, pelaksanaan penataran, pemantapan penataran.

Keempat, pemberangkatan meliputi koordinasi tentang jadwal pemberangkatan, menyiapkan secara pelepasan/pemberian doa restu, pengecekan kelengkapan administrasi, pengaturan teknis pemberangkatan, pengantar pemberangkatan. Kelima, pelaksanaan meliputi membuat jadwal kegiatan sebelum melaksanakan kegiatan, memberikan penjelasan/pemantapan, melaksanakan seluruh rangkaian kegiatan sesuai jadwal dan aturan dari kemenag dan pemerintah Arab Saudi, evaluasi terhadap kegiatan. Keenam, pemulangan meliputi koordinasi tentang jadwal pemulangan, memberikan penjelasan tentang hal-hal yang berkaitan dengan jadwal pemulangan, pengecekkan personel dan materil pemulangan. Ketujuh, pembinaan purna haji melputi membuat piagam haji, merencanakan pertemuan setiap 2 (dua) bulan sekali, membuat jadwal/acara untuk mengisi pertemuan.

KBIH Bintaldam III/Siliwangi dalam menetapkan regulasi layanan tentunya berdasarkan hasil musyawarah bersama seluruh pengurus. Yang tercantum dalam regulasi layanan ini diantaranya: 1) Memberikan jaminan kepada jamaah akan kualitas pelayanan prima; 2) Memberikan fokus pelayanan prima kepada jamaah; 3) Menjadi alat komunikasi antara jamaah dengan pengurus $\mathrm{KBIH}$ dalam upaya meningkatkan pelayanan prima; 4) Menjadi alat untuk mengukur kinerja pelayanan serta menjadi alat monitoring dan evaluasi kinerja pelayanan prima; 5) Untuk standar pelayanan prima sehingga mengurangi kesalahan dan kelalaian; 6) Membantu pengurus agar lebih mandiri; 7) Meningkatkan akuntabilitas $\mathrm{KBIH}$; 8) Memperjelas target pekerjaan; 9) Bagi pimpinan menyediakan mekanisme informasi dalam perumusan manajemen pelayanan prima.

Adapun rincian penggunaan biaya bimbingan untuk setiap jamaah calon haji sesuai kesepakatan, yaitu: 1) Biaya perjalanan ibadah haji (BPIH) dan biaya operasional Pembimbing $=$ Rp. 1.000.000; 2) Transportasi Bandung - Asrama Haji Bekasi (PP) = Rp. 735.000; 3) Konsumsi selama bimbingan manasik haji = Rp. 400.000; 4) Insentif pemateri dan petugas manasik = Rp. 150.000; 5) Biaya operasional kegiatan haji = Rp. 300.000; 5) Perlengkapan : Pertama, batik seragam haji $=$ Rp. 150.000. Kedua, buku panduan manasik haji $=$ Rp. 50.000. Ketiga, sal jamaah haji $=$ Rp. 30.000. Keempat, rambang kopor haji $=$ Rp. 35.000. Total biaya 
$=$ Rp. 2.850.000.

Lahirnya undang-undang Nomor 13 Tahun 2008 tentang penyelenggaraan ibadah haji melalui Lembaran Negara Republik Indonesia Tahun 2008 Nomor 60 yang tidak lain sebagai pengganti dari undang-undang sebelumnya yakni undangundang nomor 17 tahun 1999 yang merupakan jawaban dari berbagai tuntutan agar penyelenggaraan ibadah haji diharapkan jauh lebih baik. Sebab sedemikian pentingnya penyelenggaraan ibadah haji bagi umat islam di Indonesia, maka sudah sepantasnya semua upaya dalam rangkaian penyempurnaan penyelenggaraan ibadah haji mendapat perhatian sepenuhnya dari semua aparatur negara.

Perubahan undang-undang penyelenggaraan ibadah haji melalui undangundang nomor 13 tahun 2008, saat ini telah dihasilkan oleh DPR RI dan pemerintah, perubahan ini merupakan inisiatif perbaikan kebijakan yang patut mendapatkan apresiasi dari semua pihak dalam rangka mewujudkan pelayanan penyelenggaraan haji yang optimal. Hal tersebut sebagai salah satu bentuk manifestasi pertanggungjawaban negara dalam menjamin kemerdekaan setiap warga negaranya untuk menjalankan perintah agama dan kepercayaan masingmasing.

Kendati demikian kehadiran undang-undang tersebut sebagai salah satu perangkat hukum tidak serta merta dapat menjadi jaminan bagi terselenggaranya pelayanan ibadah haji yang lebih baik. Menurut Soerjono Soekanto, penegakan hukum dalam suatu negara tidak hanya ditunjang oleh perangkat hukum yang sistematis, melainkan juga mesti didukung sepenuhnya oleh aparat hukum yang berwibawa serta kesadaran hukum masyarakat adalah kesadaran yang ada pada setiap manusia tentang apa itu hukum atau apa seharusnya hukum itu.

Kesadaran hukum masyarakat merupakan suatu kategori tertentu dari hidup (kejiwaan) manusia yang dapat membedakan antara hukum dan tidak hukum antara yang sepantasnya dilakukan dan tidak dilakukan. Dalam peraturan menteri kehakiman RI Nomor 05.PR-08.10 Tahun 1988 tentang pola pemantapan dan penyuluhan hukum dinyatakan bahwa kesadaran hukum masyarakat adalah nilainilai yang hidup dalam masyarakat tentang hukum yang meliputi pengetahuan, pemahaman, penghayatan, dan kepatuhan atau ketaatan pada hukum. Pada intinya kesadaran hukum masyarakat merupakan pandangan yang hidup dalam masyarakat bukanlah produk dari agama, budaya, ekonomi, politik dan sebagainya.

Regulasi layanan yang ditetapkan oleh KBIH Bintaldam III/Siliwangi ini merupakan salah satu upaya dalam meningkatkan kualitas pelayanan prima. Dalam menetapkan regulasi layanan, tentunya mengandung fungsi-fungsi manajemen. Pada umumnya setelah melakukan perencanaan, setiap organisasi melakukan fungsi berikutnya, yaitu pelaksanaan, begitu pula dengan KBIH Bintaldam III/Siliwangi. Setelah menyiapkan perencanaan program, kemudian para pengelola KBIH melaksanakan atau menerapkan apa yang ada dalam perencanaan tersebut. Kemudian di bagian akhir ada evaluasi yang berguna untuk mengukur sejauh mana pencapaian target yang telah dilaksanakan. Dari semua fungsi manajemen itu, tentunya ada regulasi yang berfungsi untuk memberikan kepastian, 
kejelasan, sasaran dan arahan terhadap setiap aktivitas dan program demi tercapainya tujuan dari lembaga tersebut.

Hal tersebut senada dengan tujuan manajemen yang dikemukakan oleh ahli manajemen yang menjelaskan bahwa tujuan adalah hasil yang diinginkan yang melukiskan skop yang jelas, serta memberikan arah kepada usaha-usaha seorang manajer mencakup empat pokok, yaitu tujuan/sasaran, skop, kepastian dan arah. Kita tahu bahwa segala sesuatu membutuhkan manajemen yang baik sehingga tujuan yang diinginkan berhasil dicapai (Terry, 2005:17).

Seperti yang ada di KBIH Bintaldam III/Siliwangi ini yang begitu memperhatikan kualitas manajemen, sehingga lembaga ini selalu memberikan pelayanan prima kepada jamaahnya. Tujuan dan arah yang dibuat dalam regulasi lembaga ini pun memperjelas langkah kinerja setiap pengurusnya dalam melaksanakan segala aktivitas mulai dari kelengkapan administrasi, manasik haji, hingga teknis pelaksanaan ibadah haji. KBIH Bintaldam III/Siliwangi sangatlah memperhatikan aspek-aspek terhadap individu, mulai dari pembagian kerja sesuai struktur yang telah dibuat oleh KBIH Bintaldam III/Siliwangi, hingga timbulah rasa saling menghormati dan menghargai antara sesama pengurus, serta timbul pula rasa ingin memberikan pelayanan yang baik kepada pengguna jasa KBIH Bintaldam III/Siliwangi, yaitu para calon jamaah haji.

Melihat upaya pengolaan yang dilakukan oleh $\mathrm{KBIH}$ Bintaldam III/Siliwangi dalam rangka memberikan pelayanan prima terhadap jamaah sangat baik, nampaknya selain untuk meningkatkan pelayanan prima tersebut, langkah ini juga merupakan upaya KBIH dalam mempertahankan eksistensi lembaganya dalam persaingan dengan lembaga lain yangbergerak dibidang yang sama yaitu lembaga pelayanan haji, sebagaimana yang dikatakan Porter yang mengaitkan strategi dengan upaya organisasi untuk mencapai keunggulan bersaing, bahkan dikatakan bahwa energi adalah alat penting dalam rangka mencapai keunggulan bersaing. Selain itu, strategi yang dilakukan oleh KBIH Bintaldam III/Siliwangi juga sebagai alat untuk mencapai tujuan organisasi.

Pada dasarnya yang dimaksud dengan strategi bagi manajemen pelayanan prima adalah rencana berskala besar yang berorientasi pada jangka panjang yang jauh ke masa depan serta menetapkan sedemikian rupa sehingga memungkinkan organisasi memaksimalkan pelayanan terhadap jamaah yang diarahkan pada optimalisasi pencapaian tujuan dan berbagai sasaran yang bersangkutan. Hal tersebut senada dengan strategi yang dilakukan oleh $\mathrm{KBIH}$ Bintaldam III/Siliwangi dalam rangka menciptakan dan memberikan pelayanan prima bagi para jamaah. Salah satunya interaksi yang baik dengan para jamaah.

Dengan demikian, upaya pelayanan prima yang dilakukan KBIH Bintaldam III/Siliwangi ini merupakan hal yang tidak dapat dipisahkan dari berjalannya kelancaran setiap langkah dalam mencapai tujuan yang telah diatur dalam regulasi layanan lembaga tersebut.

KBIH Bintaldam III/Siliwangi sebagai lembaga yang menjual produk berupa jasa, tidak akan pernah terlepas dari yang namanya aktivitas pelayanan dan 
akan banyak berhubungan dengan masyarakat, dalam hal ini adalah para calon jamaah haji yang mendaftarkan diri sebagai pengguna jasa bimbingan manasik haji di KBIH Bintaldam III/Siliwangi. Komunikasi yang dibangun lembaga tentunya harus baik, agar tercipta hubungan yang baik pula terhadap para jamaah, sehingga upaya untuk meningkatkan kualitas pelayanan prima akan tercapai.

Regulasi adalah aktivitas seputar peraturan yang menggambarkan persaudaraan diantara kekuatan politik dari kelompok berkepentingan (eksekutif/industri) sebagai sisi permintaan/demand dan legislatif sebagai supply (Stigler, 1971:14). Teori ini berpendapat bahwa dibutuhkan aturan-aturan atau ketentuan dalam manajerial pelayanan. Ketentuan diperlukan agar semuanya baik pemakai maupun penyaji jasa mendapatkan informasi yang sama dan seimbang.

\section{Fasilitas-fasilitas Layanan di KBIH Bintaldam III/Siliwangi}

Dalam melaksanakan program atau aktivitas yang dilakukan oleh setiap lembaga, organisasi atau perusahaan, tentunya didukung oleh fasilitas-fasilitas layanan yang dapat memudahkan pelaksanaan program tersebut. Sama halnya dengan KBIH Bintaldam III/Siliwangi yang selalu meningkatkan kualitas fasilitas-fasilitas layanan demi tercapainya tujuan pelayanan prima. Seiring perkembangan informasi dan teknologi, KBIH Bintaldam III/Siliwangi pun tidak ketinggalan zaman untuk selalu up to date agar pelayanan semakin prima. Hal ini bisa dilihat dari jumlah jamaah haji yang selalu meningkat karena kualitas fasilitas-fasilitas dan pelayanan yang sangat prima di KBIH ini. Adapun fasilitas-fasilitas layanan yang dipergunakan di KBIH Bintaldam III/Siliwangi, yaitu: 1) Konsultasi gratis; 2) Layanan informasi; 3) Miniatur Kabah dan jamarot; 4) Lapangan yang cukup luas; 5) Mesjid; 6) Wc (toilet); 7) Ruangan kantor; 8) Telepon kantor; 9) Printer; 10) Laptop + komputer + proyektor (audio visual); 11) Buku panduan manasik haji; 12) Sound System; 13) Denah perjalanan haji dan perlengkapan lainnya.

Sebagai salah satu upaya meningkatkan pelayanan prima terhadap jamaah haji, KBIH Bintaldam III/Siliwangi juga memberikan manasik haji yang baik, memberikan fasilitas bimbingan dan pelatihan yang baik pula, dengan tenaga pembimbing yang ahli di bidangnya. Metode atau cara penyampaian materi yang diberikan oleh para pembimbing juga bermacam-macam.

Maka dari segi penyampaian materi dapat dibagi menjadi 2 cara, yaitu: Pertama, metode tradisional, metode ini adalah seperti halnya ceramah umum, dalam metode ini pembimbing aktif berbicara sedangkan jamaah hanya medengarkan saja. Adapun untuk menghafal doa-doa yang ada dalam rangkaian pelaksanaan ibadah haji para pembimbing menuntun jamaah dengan cara dibaca bergantian antara pembimbing dan jamaah. Kedua, metode modern, metode ini adalah seperti halnya diskusi, seminar dan sejenisnya yang di dalamnya terjadi komunikasi dua arah dengan menggunakan teknologi seperti proyektor, laptop dan fasilitas lainnya yang menunjang bagi kegiatan ini. Serta yang penting dalam metode ini terjadi proses tanya jawab antara jamaah dan pembimbing.

Kedua metode tersebut merupakan bagian dari bentuk upaya KBIH dalam meningkatkan pengetahuan jamaah haji sekaligus bentuk pelayanan dengan 
mengoptimalkan fasilitas yang telah disediakan agar tercapainya tujuan pelayanan prima.

Fasilitas-fasilitas layanan merupakan bagian dari pemberian pelayanan prima, tanpa adanya fasilitas yang baik, keberhasilan yang akan dicapai oleh KBIH Bintaldam III/Siliwangi kemungkinan akan kecil. Hal ini juga sangat diperhatikan sekali oleh para pengurus KBIH Bintaldam III/Siliwangi dalam proses pelayanan terhadap jamaah haji dan dalam strategi mempertahankan kepercayaan dari para calon jamaah, karena pada dasarnya fasilitas yang baik akan menimbulkan hasil yang baik bagi sebuah organisasi khususnya dalam segi pelayanan prima. Berdasarkan fakta dan pengamatan yang telah dilakukan oleh penulis, maka penulis dapat menyimpulkan bahwa di KBIH ini telah memiliki fasilitas-fasilitas yang memadai dalam memberikan pelayanan prima terhadap jamaah sehingga kualitas manajemennya pun bisa dikatakan sangat baik.

Proses untuk mencapai pelayanan yang prima telah dilakukan oleh $\mathrm{KBIH}$ Bintaldam III/Siliwangi yakni melalui fasilitas-fasilitas (sarana dan pra sarana) yang digunakan di KBIH Bintaldam III/Siliwangi. Hal ini dilakukan agar para calon jamaah haji dapat melaksanakan serangkaian proses ibadah haji di Tanah Suci dengan baik, dan tidak canggung ketika dihadapkan pada ibadah yang nyata, yakni ketika sudah di Tanah Suci. Selain fasilitas sarana dan prasarana yang memadai, KBIH Bintaldam III/Siliwangi juga memberikan konsultasi gratis bagi calon jamaah. Faktor fasilitas layanan ini sangat berpengaruh pada upaya yang dilakukan oleh KBIH Bintaldam III/Siliwangi dalam meningkatkan kualitas pelayanan prima, yaitu dapat memberikan rasa nyaman bagi orang-orang yang berkepentingan serta dapat menimbulkan perasaan puas pada orang-orang yang berkepentingan dalam hal ini adalah para pengguna jasa (calon jamaah haji) $\mathrm{KBIH}$ Bintaldam III/Siliwangi.

Sebagai lembaga yang telah berdiri cukup lama, KBIH Bintaldam III/Siliwangi memiliki kiat-kiat tersendiri dalam memberikan pelayanan prima terhadap jamaah. Salah satunya dengan meningkatkan kualitas fasilitas-fasilitas layanan demi kenyamanan dan kepuasan jamaah. Faktor kesadaran dari setiap pengurus akan pentingnya merawat fasilitas-fasilitas layanan memiliki peranan yang penting dalam setiap aktivitas pelaksanaan dan pelayanan prima di $\mathrm{KBIH}$ Bintaldam III/Siliwangi. Fasilitas-fasilitas layanan yang baik sangat menunjang keberhasilan suatu kegiatan. Maka dari itu, KBIH Bintaldam III/Siliwangi selalu berupaya untuk meningkatkan dan memperbaiki fasilitas-fasilitas layanan demi tercapainya tujuan pelayanan prima.

Dalam mendefinisikan pelayanan prima minimal harus ada tiga hal pokok, yaitu adanya pendekatan sikap yang berkaitan dengan kepedulian kepada pelanggan, upaya melayani dengan tindakan terbaik dan ada tujuan untuk memuaskan pelanggan dengan berorientasi pada standar layanan tertentu (Barata, 2003:26). Begitu pula dgn KBIH Bintaldam III/Siliwangi yang senantiasa meningkatkan dan mengembangkan fasilitas-fasilitas untuk memberikan kenyamanan dan kepuasan kepada jamaah. 


\section{Budaya Pemberian Layanan di KBIH Bintaldam III/Siliwangi}

Setiap organisasi, lembaga atau perusahaan memiliki cara khas dalam memberikan layanan kepada pelanggan. Hal inilah yang disebut dengan budaya pemberian layanan. Di KBIH Bintaldam III/Siliwangi pun memiliki budaya pemberian layanan yang khas. KBIH Bintaldam III/Siliwangi ini bisa dibilang unik karena dikelola oleh aparat pemerintahan yakni TNI. Walaupun tentara dikenal dengan sifat tegas dan "galak"nya, namun petugas $\mathrm{KBIH}$ ini sangatlah ramah dalam melayani tamu dan pelanggan. Tentunya yang paling berpengaruh dalam pelayanan prima ini adalah pilar-pilar kedisiplinan yang tertanam di $\mathrm{KBIH}$ Bintaldam III/Siliwangi ini. Terlihat dari kesadaran pribadi dari setiap anggota $\mathrm{KBIH}$ tersebut untuk selalu memberikan pelayanan yang terbaik kepada pelanggan dengan efektif dan efisien. Dengan antusiasme tinggi yang ditunjukkan oleh anggota $\mathrm{KBIH}$ kepada pelanggan tentunya semakin menarik hati dan minat pelanggan terhadap kualitas pelayanan KBIH ini. Namun tak sebatas itu, KBIH ini selalu melakukan perbaikan dan peningkatan kinerja pelayanan dari waktu ke waktu agar kualitas pelayanan prima tidak menurun.

Pada dasarnya, setiap organisasi adalah suatu integrasi elemen-elemen yang semuanya bekerjasama untuk mencapai suatu tujuan. Semua sistem mencakup tiga unsur utama, yaitu, input, transformasi dan output. Setiap organisasi tentu mempunyai strategi masing-masing untuk memenuhi setiap kebutuhannya, termasuk kebutuhan terhadap berlangsungnya organisasi, baik dalam hubungan interpersonal ataupun personal, sebagai salah satu organisasi yang berdiri di bidang pelayanan jasa, KBIH mempunyai budaya tersendiri dalam upaya mempertahankan keberadaannya di tataran organisasi dewasa ini.

Salah satu upaya yang sangat diperhatikan adalah mengenai pelayanan terhadap jamaah, dalam melayani jamaah KBIH Bintaldam III/Siliwangi memiliki budaya khasnya dalam melayani dan memberikan informasi kepada calon jamaahnya, diantaranya: Pertama, simple (mudah), kemudahan memperoleh pelayanan dan kejelasan informasi menjadikan jamaah haji semakin puas karena relatif mudah, nyaman dan efisien dalam mendapatkan layanan di KBIH ini. Sehingga jamaah haji tidak merasa dipersulit dalam urusannya dalam KBIH ini.

Kedua, cheap but good (murah tapi bagus), hemat waktu dan tenaga, murah harga dengan kualitas dan manfaat yang baik. Tentunya semua orang pun tertarik dengan hal tersebut. Jamaah menilai value berdasarkan besarnya manfaat yang diterima dibandingkan dengan pengorbanan yang dikeluarkan baik dalam bentuk besarnya uang yang dikeluarkan, waktu dan usahanya. Menariknya, biaya bimbingan di KBIH Bintaldam III/Siliwangi ini jauh lebih murah dari KBIH yang lain. Tentunya walaupun dengan harga murah, namun kualitas pelayanan di KBIH ini sangat maksimal dan tidak mengecewakan.

Ketiga, motivation (motivasi), pentingnya motivasi masing-masing pribadi individu serta kaitannya dengan kekuatan dari keteladanan pimpinan dan monitoring pengawasan sehingga akan mewujudkan dan menciptakan atmosfer kelangsungan budaya pelayanan prima. Seperti yang dilakukan di KBIH Bintaldam 
III/Siliwangi ini yang penuh dengan motivasi setiap anggota dan monitoring dari pimpinan sehingga kualitas manajemen $\mathrm{KBIH}$ dapat terlihat dari maksimalnya pelayanan prima kepada pelanggan/jamaah.

Keempat, dicipline (disiplin), kedisiplinan adalah suatu keharusan bagi setiap lembaga, organisasi maupun individu. Seperti halnya dengan KBIH Bintaldam III/Siliwangi ini yang membudayakan kedisiplinan dalam melaksanakan setiap aktivitas KBIH. Sehingga mulai dari awal bimbingan di tanah air hingga di tanah suci pun jamaah haji selalu tertib.

Kelima, fast (cepat), kualitas pelayanan prima dalam suatu organisasi atau lembaga dapat dilihat dari kecekatan petugas dalam melayani pelanggan/jamaah. Begitu juga dengan budaya yang diterapkan di KBIH ini. Apalagi para petugas KBIH Bintaldam III/Siliwangi ini merupakan anggota TNI yang tentunya dikenal disiplin dan cekatan dalam melakukan tugas atau sesuatu. Sehingga jamaah haji pun merasa puas dengan pelayanan di KBIH ini.

Keenam, word of mouth (mulut ke mulut), dikenal dengan sebutan dari mulut ke mulut, rupanya hal ini telah menjadi budaya di KBIH ini dalam memberikan informasi layanan kepada calon jamaah. Menurut pengurus KBIH tersebut, budaya itu sudah ada sejak awal didirikan KBIH Bintaldam III/Siliwangi. Uniknya tak kalah dengan media informasi yang berbasis teknologi saat ini yang semakin berkembang pesat. Buktinya jamaah di KBIH ini selalu banyak tiap tahunnya. Berdasarkan hasil wawancara kepada alumni haji di KBIH ini menerangkan bahwa budaya pelayanan sangat memberikan kenyamanan dan kepuasan mulai dari awal sampai akhir kegiatan haji.

Ketujuh, pemberdayaan alumni, ini adalah budaya yang mengikat ukhuwah islamiyah antara alumni haji dengan pengurus KBIH Bintaldam III/Siliwangi. Selain itu, langkah ini sangatlah membantu lembaga ini agar semakin dikenal oleh masyarakat luas. Para alumni ini menceritakan tentang KBIH Bintaldam III/Siliwangi kepada para calon jamaah haji yang membutuhkan tempat bimbingan, baik itu untuk pergi umrah ataupun pergi haji, dan kemudian banyak para calon jamaah haji yang berminat untuk mengikuti bimbingan manasik haji di KBIH Bintaldam III/Siliwangi. Selain itu, budaya ini juga akan mempermudah lembaga ini mendapatkan kepercayaan dari calon jamaah haji, sehingga para calon jamaah haji akan memilih lembaga ini sebagai sarana untuk memperoleh keilmuan sebelum berangkat ke tanah suci.

Budaya ini sangat berguna bagi eksistensi KBIH Bintaldam III/Siliwangi ini terutama dalam mempertahankan jalinan ukhuwah islamiyah. Budaya pelayanan prima tersebut sangat berpengaruh dalam penyebaran informasi tentang eksistensi $\mathrm{KBIH}$ ini. Dalam memuaskan para jamaah di KBIH Bintaldam III/Siliwangi, tak lepas dari budaya pelayanan prima yang telah melekat dalam setiap aktivitas KBIH tersebut. Sehingga terjalinnya sebuah keharmonisan antara pengurus $\mathrm{KBIH}$ dengan para jamaah haji. Keharmonisan yang ditimbulkan oleh budaya pelayanan prima itu tidak dibiarkan begitu saja, buktinya selalu ada kegiatan rutin antara calon, jamaah maupun alumni haji dengan para pengurus KBIH Bintaldam 
III/Siliwangi. Budaya pelayanan prima di lembaga tersebut dapat menjadi cerminan bahwa kualitas manajemen di KBIH Bintaldam III/Siliwangi sudah sangat baik.

Budaya pelayanan prima merupakan suatu ciri khas yang ada di $\mathrm{KBIH}$ Bintaldam III/Siliwangi dalam menunjang peningkatan kualitas manajemen $\mathrm{KBIH}$ sendiri. Kemudian, dalam rangka mempertahankan eksistensi dan memperkenalkan lembaga ini, KBIH Bintaldam III/Siliwangi memiliki budaya tersendiri yang cukup sederhana, yaitu dengan word of mouth atau biasa juga yang disebut dengan istilah dari mulut ke mulut dan pemberdayaan alumni. Walaupun dengan cara yang sederhana, namun KBIH Bintaldam III/Siliwangi tidak kalah dengan KBIH yang lainnya karena selalu mendapatkan banyak jamaah.

Hal ini terbukti dari banyaknya jamaah dari waktu ke waktu berdasarkan data yang diperole. Kemudian, kemudahan, kedisiplan dan kecepatan menjadi budaya layanan di KBIH Bintaldam III/Siliwangi. Contohnya kemudahan dalam mendapatkan informasi dan mengurus administrasi. Lalu kedisiplinan dan kecepatan dalam setiap aktivitas dan layanan terhadap jamaah. KBIH Bintaldam III/Siliwangi sebagai lembaga yang berada di bawah naungan TNI, menambah nilai positif bagi kinerja pelayanan di $\mathrm{KBIH}$ tersebut. Selain itu, bentuk keberhasilan yang telah dicapai oleh KBIH Bintaldam III/Siliwangi ini diperoleh dari budaya pelayanan prima para pengurus yang cenderung transparan, komunikatif dan ramah kepada para calon jamaah haji.

Salah satu pelayanan yang sangat baik diterima oleh para calon jamaah haji adalah kesiapan KBIH membimbing para calon jamaah haji dari mulai pendaftaran, bimbingan manasik, pemberangkatan hingga pemulangan kembali ke Tanah Air. Kemudian dalam proses manasik haji, KBIH Bintaldam III/Siliwangi juga sangat terbuka bagi para calon jamaah haji yang ingin mengikuti serangkaian proses manasik haji, meskipun calon haji tersebut tidak akan berangkat pada tahun yang bersangkutan. Selain itu, salah satu bentuk kesuksesan yang telah diperoleh KBIH Bintaldam III/Siliwangi adalah banyaknya para calon jamaah haji yang mendaftarkan diri untuk bergabung dan melakukan bimbingan di $\mathrm{KBIH}$ Bintaldam III/Siliwangi. Keberhasilan yang dicapai oleh KBIH Bintaldam III/Siliwangi tidak terlepas dari peran para pengurus di dalamnya, yaitu ketua, para pengurus dan para pembimbing yang terlibat di dalamnya. Sejauh ini upaya yang dilakukan oleh pengurus KBIH Bintaldam III/Siliwangi telah mendapat tanggapan yang positif dari para calon jamaah haji yang telah terdaftar sebagai jamaah di KBIH Bintaldam III/Siliwangi.

Salah satu faktor yang harus ada agar dapat diselenggarakan pelayanan yang berkualitas adalah adanya budaya pelayanan yang berorientasi kepada kepentingan pelanggan atau pengguna jasa (Ratminto, \& Winarsih, S. A., 2016:117).

\section{PENUTUP}

Manajemen pelayanan prima merupakan suatu dasar aturan dalam suatu organisasi atau lembaga. Setiap orang dimanapun berada akan merasakan dampak 
baik atas adanya layanan yang prima sehingga setiap orang mendapatkan kepuasan tersendiri. Kepuasan itu merupakan salah satu tolak ukur keberhasilan manajemen pelayanan prima dalam organisasi atau lembaga yang bersangkutan.

KBIH Bintaldam III/Siliwangi dalam hal ini telah membuktikan keberhasilannya dalam mengelola layanan secara sangat baik. Hal ini terbukti dari banyaknya jamaah dari tahun ke tahun walaupun KBIH ini tidak melakukan propaganda secara khusus kepada para calon jamaah. Banyaknya jamaah juga diperoleh karena kualitas KBIH ini telah teruji sangat baik.

Berdasarkan sekian banyak pembahasan yang telah dipaparkan dari hasil penelitian di KBIH Bintaldam III/Siliwangi, dapat ditarik kesimpulan sebagai berikut: pertama, regulasi layanan yang dilakukan oleh KBIH Bintaldam III/Siliwangi dalam meningkatkan dan memberikan pelayanan prima dianggap mampu memberikan kontribusi yang efektif dalam mempertahankan lembaga tersebut. Adapun regulasi layanan di KBIH Bintaldam III/Siliwangi sebagai berikut: 1) memberikan jaminan kepada jamaah akan kualitas pelayanan yang dipertanggungjawabkan; 2) memberikan fokus pelayanan kepada jamaah; 3) menjadi alat komunikasi antara jamaah dengan pengurus $\mathrm{KBIH}$ dalam upaya meningkatkan pelayanan prima; 4) menjadi alat untuk mengukur kinerja pelayanan prima serta menjadi alat monitoring dan evaluasi kinerja pelayanan prima; 5) untuk standarisasi sehingga mengurangi kesalahan dan kelalaian; 6) membantu pengurus KBIH lebih mandiri; 7) meningkatkan akuntabilitas; 8) menciptakan ukuran standar kinerja; 9) Memperjelas target pekerjaan; 10) Bagi pimpinan menyediakan mekanisme informasi dalam perumusan manajemen pelayanan prima. Kedua, fasilitas-fasilitas layanan yang ada di KBIH Bintaldam III/Siliwangi merupakan salah satu bukti dari hasil manajemen pelayanan prima yang telah diterapkan oleh KBIH Bintaldam III/Siliwangi.

Berikut fasilitas-fasilitas layanan yang ada di KBIH Bintaldam III/Siliwangi: 1) konsultasi gratis; 2) layanan informasi; 3) miniatur Kabah dan jamarot; 4) lapangan yang cukup luas; 5) masjid; 6) wc (toilet) / kamar mandi; 7) ruangan kantor; 8) Telepon kantor; 9) printer; 10) laptop + komputer + proyektor (audio visual); 11) buku panduan manasik haji; 12) Sound System; 13) denah perjalanan haji dan perlengkapan lainnya.

Ketiga, budaya pelayanan prima di KBIH Bintaldam III/Siliwangi antara lain sebagai berikut: 1) simple (mudah), kemudahan memperoleh pelayanan dan kejelasan informasi menjadikan jamaah haji semakin puas karena relatif mudah, nyaman dan efisien dalam mendapatkan layanan di KBIH ini. Sehingga jamaah haji tidak merasa dipersulit dalam urusannya dalam KBIH ini; 2) cheap but good (murah tapi bagus), walaupun biaya bimbingan di KBIH Bintaldam III/Siliwangi terbilang lebih murah dari KBIH yang lain, namun pelayanannya tidak "murahan" (bagus); 3) motivation (motivasi), KBIH Bintaldam III/Siliwangi dalam memberikan pelayanan prima kepada jamaah tentunya tidak lepas dari motivasi dari semua pihak yang terlibat khususnya pimpinan dan pengurus $\mathrm{KBIH}$; 4) discipline (disiplin), faktor ini rupanya telah melekat dalam manajerial pelayanan di 
KBIH Bintaldam III/Siliwangi ini. Hal ini dapat dilihat dari kesigapan setiap pengurus dalam melaksanakan tugasnya masing-masing dan melayani jamaah; 5) fast (cepat), kualitas pelayanan prima dalam suatu organisasi atau lembaga dapat dilihat dari kecekatan petugas dalam melayani pelanggan/jamaah. Begitu juga dengan budaya yang diterapkan di KBIH ini. Apalagi para petugas $\mathrm{KBIH}$ Bintaldam III/Siliwangi ini merupakan anggota TNI yang tentunya dikenal disiplin dan cekatan dalam melakukan tugas atau sesuatu. Sehingga jamaah haji pun merasa puas dengan pelayanan di KBIH ini; 6) word of mouth (mulut ke mulut), hal ini rupanya telah menjadi ciri khas dari KBIH Bintaldam III/Siliwangi ini dalam menyebarkan informasi dan memperkenalkan eksistensinya. Namun tak kalah dengan lembaga lain karena selalu banyak jamaah di KBIH Bintaldam III/Siliwangi ini; 7) pemberdayaan alumni, karena KBIH Bintaldam III/Siliwangi sadar akan pentingnya peranan alumni jamaah haji, maka dari itu KBIH ini selalu mengadakan kegiatan dalam rangka mempererat jalinan ukhuwah islamiyah antara pengurus KBIH dengan para alumni. Selain itu, para alumni juga berperan sebagai media penyebaran informasi KBIH Bintaldam III/Siliwangi.

Berdasarkan peneltian yang telah dilakukan di $\mathrm{KBIH}$ Bintaldam III/Siliwangi tentang manajemen pelayanan prima, maka ada beberapa saran yang perlu diperhatikan baik untuk lembaga yang diteliti maupun untuk penelitian selanjutnya.

Pertama, Untuk meningkatkan kualitas pelayanan prima kepada para jamaah, hendaknya lembaga ini dapat memberikan kesempatan (merekrut) kepada orang lain yang dinilai berkompeten dalam urusan haji agar semakin terbantu dan lancarnya setiap kegiatan $\mathrm{KBIH}$, sehingga dalam pelaksanaanya, tujuan $\mathrm{KBIH}$ dapat tercapai dengan baik. Pengelolaan layanan prima secara professional akan dapat meningkatkan kualitas manajemen serta akan dapat mengoptimalkan pelayanan prima dengan lebih baik lagi.

Kedua, Dalam mempertahankan eksistensi dan memperkenalkan KBIH, alangkah lebih baiknya jika menggunakan teknologi terkini seperti internet dan media sosial. Tentunya dengan langkah ini akan mempermudah lembaga dalam memberikan informasi kepada masyarakat luas dan mendapatkan calon jamaah meski KBIH Bintaldam III/Siliwangi ini bukan lembaga yang berkecimpung dalam bidang bisnis murni. Di samping itu juga, media tersebut dapat dimanfaatkan untuk menjalin dan mempererat komunikasi serta silaturahmi antara pengurus dengan jamaah maupun alumni haji.

\section{DAFTAR PUSTAKA}

Barata, A. A. (2003). Dasar-dasar Pelayanan Prima. Jakarta: PT. Gramedia Pustaka. Basyuni, M. M. (2008). Formula Pelayanan Prima dalam Penyelenggaraan Ibadah Haji. Jakarta: FDK Press.

Basyuni, M. M. (2008). Reformasi Manajemen Haji. Jakarta: FDK Press. Handoko, H. T. (2012). Manajemen. Yogyakarta: BPFE Yogyakarta.

Hasibuan, P. S. M. (2009). Manajemen Dasar, Pengertian dan Masalah. Jakarta: Bumi 
Aksara.

Muhyiddin, A. (2010). Dakwah Lingkungan Perspektif Al-Qur'an. Ilmu Dakwah: Academic Journal for Homiletic Studies [Online], 5(15) 809-826. Web. 6 Mar. 2018

Munir, M., \& Ilaihi, W. (2006). Manajemen Dakwah. Jakarta: Prenada Media.

Norman, Levine. (1991). Pelayanan Jasa. Edisi Kedua. Yogyakarta: Gajah Mada University Press

Rahmayanty, N. (2010). Manajemen Pelayanan Prima. Yogyakarta: Graha Ilmu.

Rasyid, S. (2002). Fiqib Islam. Jakarta: Attahiriyah

Ratminto, \& Winarsih, S. A. (2016). Manajemen Pelayanan. Yogyakarta: Pustaka Pelajar.

Samsudin, S. (2010). Manajemen Sumber Daya Manusia. Bandung: CV Pustaka Setia Shaleh, R. (1986). Manajemen Dakwah Islam. Jakarta: Bulan Bintang.

Stigler, G.J. (1971). Bell Journal of Economics and Management. Chicago: University of Chicago Press

Terry, R. G (2005). Dasar-dasar Manajemen. Jakarta: Bumi Aksara 